\title{
Correction to: Comparison of Female Athlete Triad (Triad) and Relative Energy Deficiency in Sport (RED-S): a Review of Low Energy Availability, Multidisciplinary Awareness, Screening Tools and Education
}

\author{
Alexandra Warrick ${ }^{1} \cdot$ Marcia Faustin $^{1} \cdot$ Brandee Waite $^{1}$ iD \\ Published online: 12 November 2020 \\ (C) Springer Science+Business Media, LLC, part of Springer Nature 2020
}

Correction to: Current Physical Medicine and Rehabilitation Reports. https://doi.org/10.1007/s40141-020-00296-y

The original version of this article unfortunately contained a mistake in the Title. "Relative Energy Deficiency in Syndrome (RED-S)" should be presented as "Relative Energy Deficiency in Sport (RED-S)".

The original article has been corrected.

Publisher's Note Springer Nature remains neutral with regard to jurisdictional claims in published maps and institutional affiliations.

The original article can be found online at https://doi.org/10.1007/ s40141-020-00296-y

\section{Brandee Waite}

blwaite@ucdavis.edu

1 Department of Physical Medicine and Rehabilitation, Sports Medicine, University of California Davis School of Medicine, 3301 C Street, Suite1600, Sacramento, CA 95816, USA 